\title{
Kepemimpinan Kepala Sekolah dalam Peningkatan Mutu Sekolah Melalui Pengawasan Proses Belajar Mengajar (Studi Kasus: di SMPN 26 Baru Kota Malang)
}

\author{
Sudari \\ IKIP Budi Utomo Malang \\ sudari@gmail.com
}

\begin{abstract}
The prominent and important headmaster the supervision This aimed knowing headmaster leaderships of 26 Junior School of Malang in the quality, knowing the headmaster role of SMPN 26 of Malang City in implementing the supervision role to improve the learning process in school, knowing the supporting and inhibiting factors of the headmaster of SMPN 26 of Malang city in implementing the supervision role in improving the learning process in school. Data collected document observation depth to teachers, headmaster of vice public staffs, and analyzed descriptive qualitative technique. on analysis showed ( ) style SMPN 26 of Malang city tend to use democratic participative leadership and authoritarian leadership style in urgent condition ( 2 ) the headmaster role of SMPN 26 of Malang city in improving the learning process by giving intensive cultivation to the teachers through individual supervision, direct class observation ( 3 ) implementation direct supervision was by factors, either - porting or inhibiting factors.
\end{abstract}

Keywords : leadership, headmaster, quality, supervision, learning process

\section{PENDAHULUAN}

Undang-Undang Dasar

(UUD) 1945 meng-amanatkan bahwa dalam upaya peningkatan kualitas dan kesejahteraan hidup semua lapisan masyarakat atau warga negara republik ini berhak mendapatkan pendidikan. Sejalan dengan Undang-Undang Nomor 20 Tahun 2003 tentang Sisdiknas, dalam pasal 5 ayat (1) disebutkan bahwa warga negara memiliki hak yang sama dalam memperoleh pendidikan yang bermutu". Dalam pasal 11 ayat 1 menyatakan " bahwa pemerintah dari semua tingkatan berkewajiban melayani dan mem berikan kemudahan, serta memberikan jaminan atas terselenggaranya pendidikan yang layak, ber mutu bagi setiap warga negara tanpa diskriminasi".

Sekolah sebagai pendidikan formal diharapkan dapat meningkatkan kualitas SDM. Dalam upaya peningkatan kualitas mutu pendidikan, maka perlu, diatur, dikelola dan diberdayakan, agar dapat menghasilkan out-put lulusan, produk atau hasil secara optimal. Sekolah memiliki komponen penting diantaranya ada guru, peserta didik, kurikulum, fasilitas sarana dan prasarana. Secara eksternal, sekolah bekerja sama dengan instansi lain secara maupun Sekolah merupakan 
institusi terdepan dalam menjalankan proses pendidikan. Dalam kegiatannya, sekolah adalah tempat yang bukan ha- nya sekedar tempat berkumpulnya guru dan peserta didik melainkan berada dalam satu tatanan sistem yang rumit dan saling berkaitan, seko lah dipandang sebagai suatu organisasi yang membutuhkan pengelolaan. Kegiatan inti organisasi sekolah sebagai pendidikan formal yaitu mengelola SDM yang menghasilkan out-put lulusan yang mampu bersaing sesuai tuntutan kebu tuhan masyarakat, serta pada gilirannya out-put sekolah diharapkan dapat berkontribusi kepada pembangunan bangsa.

Mutu dalam pendidikan formal sebagai salah satu komponen penting dalam pelaksanaan pendidikan mendapat banyak perhatian. beberapa alternatif untuk meningkatkan mutu pendidikan adalah mengikut sertakan gurugurunya ke dalam program-program pelatihan agar supaya peningkatan kompetensi dalam mengajar lebih berkualitas, selain itu juga agar mendapat perhatian adalah perbaikan sarana prasarana dan pengadaan buku pelajaran. Hal tersebut tentu harus didukung dengan kepemimpinan kepala sekolah sebagai learder dalam sekolah untuk merencanakan pengembangan sekolah demi meningkatkan mutu pendidikan sekolah. Kepala sekolah didukung oleh peran lain demi kelancaran pelaksanaan pendidikan. Peran lain itu antara lain guru, karyawan, siswa, wali murid dan tokoh masyarakat yang didorong untuk ikut terlibat dalam penyelenggaraan pendidikan mulai dari pengambilan keputusan, pelak sanaan, serta evaluasi sehingga harapan pendidikan bermutu dan berkualitas dapat tercapai (Mulyasa, 2004).

Kepemimpinan kepala sekolah menjadi penentu masa depan sekolah. Mulyasa dalam Qomar (2007:287) menyebutkan bahwa sekolah dapat berhasil dengan baik jika didukung oleh visi kepemimpinan oleh kepala sekolah itu sendiri, karena kepala sekolah merupakan pengendali dan penentu arah atas cita-cita yang akan ditempuh oleh sekolah tersebut. Mutu sekolah dan keefektifannya, serta keunggulannya tidak lepas dari tipycal kepemimpinan dan peran kepalasekolahnya. Dengan demikian, kepala sekolah memiliki kewajiban untuk menguasai berbagai macam gaya kepemimpinan dan pelaksanaannya diadaptasikan dengan kebutuhan bawahannya.

Menurut Robbins dalam buku Management Seven Edition yang dialih bahasa oleh $\mathrm{T}$ Hermaya (2005:130) beberapagaya Style kepemimpinan yang banyak mempengaruhi keberhasilan seorang leader dalam mempengaruhi perilaku pengikut-pengikutnya, diantaranya (1) kepemimpinan yaitu, pemimpin cenderung memusatkan wewenang, mendiktekan metode kerja, membuat keputusan unilateral, dan membatasi partisipasi (2) kepemimpinan demokratis yaitu, pemimpin cenderung melibatkan karyawan dalam mengambil keputusan, mendelegasikan wewenang, memotivasi partisipasi dalam memutuskan sasaran kerja, metode dan melakukan umpan balik, (3) kepemimpinan laissez-faire yaitu, kepemimpin yang umumnya 
memberikan kelompok kebebasan penuh untuk membuat keputusan dan menuntaskan pekerjaan dengan cara apa saja yang dianggap sesuai.

Selain ditentukan oleh gaya kepemimpinannya, salah satu upaya dalam meningkatkan kualitas SDM di sekolah peran yang sangat menonjol dilakukan oleh kepala sekolah adalah peran pembelajaran juga memegang peranan penting, karena kepala sekolah sebagai leader di sekolah sangat menentukan keberhasilan program pengajaran di sekolah. Sebagai leader maka seorang kepala sekolah harus memiliki kemammpuan dalam memberikan pengawasan dan petunjuk, meningkatkan motivasi tenaga kependidikan, membuka komunikasi dua arah, serta mendelegasikan job. Wahjosumijo (2002 10) mengemukakan bahwa kepala sekolah sebagai leader harus memiliki karakter seperti kepribadian, ke ahlian dasar, pengalaman dan pengetahuan profesional, pengetahuan administrasi dan pengawasan.

Dalam hal supervisi atau pengawasan yang perlu dijadikan pertimbangan sebagai dasar mensupervisi yang dilakukan kepala sekolah adalah kategori guru yang ditawarkan oleh Glickman tentang paradigma kategori guru yang terungkap dalam buku Developmental Supervision (1981), yang menggambarkan supervisi pendidikan berikut: pandangan directive supervisi pendidikan dilakukan manakala guru rendah dalam tanggung jawab, sedangkan supervisor tinggi dalam tanggung jawab, (2) sebaliknya non directive jika guru tinggi dalam tanggung jawab, sementara supervisor rendah dalam tanggung jawab, (3) collaborative jika guru dan supervisor sama-sama dalam tanggung jawab sedang.

SMPN 26 Baru kota Malang tergolong lembaga pendidikan sekolah baru dibandingkan sekolahsekolah lainnya yang sederajat disekitar kota Malang. SMPN Baru 26 kota Malang didirikan pada tahun 2012 oleh pemerintah Kota Malang atas kerja sama dengan dana hibah Australia AEPI - ESSP melalui program pembangunan unit lembaga pendidikan formal tahun anggaran 2012. Salah satu tujuan pendiriannya adalah pemerataan pendidikan agar terserap sampai kelapisan masyarakat.

SMPN Baru 26 kota Malang kalau dilihat dari lokasinya dikelilingi oleh beberapa lembaga pendidikan formal baik pendidikan swasta maupun negeri. Diantaranya, arah timur dari lokasi kurang lebih $300 \mathrm{~m}$ ada SMP Sabilillah, dan SMPN 11, dari arah utara kurang lebih $200 \mathrm{~m}$ dari lokasi ada MTS YPI Ts. Berdasarkan hasil observasi dan wawancara awal dengan kepala sekolah SMPN 26 Baru Kota Malang diungkapkan bahwa kedepannya walaupun tergolong lembaga pendidikan formal yang masih baru didirikan akan terus diupayakan peningkatan mutu sekolah agar di masyarakat punya tempat dan dapat diterima dengan cepat. Hal tersebut, tergambar dalam visi SMPN 26 Baru Kota Malang adalah mewujudkan insan yang bertaqwa, cerdas, terampil, berbudi pekerti yang luhur dan berbudaya lingkungan. Untuk mewujudkan visi tersebut, maka misi yang dibangun adalah; 
mewujudkan pemahaman dan penghayatan, serta pengamalan keagamaan bagi peserta didik di sekolah, (2) membudayakan potensi kecerdasan yang dimiliki oleh peserta didik, (3) mewujudkan pembelajaran berbasis keterampilan proses untuk meningkatkan kecakapan hidup peserta didik, (4) meningkatkan tanggung jawab, dan percaya diri, serta semangat untuk berkompetensi pada peserta didik, (5) mewujudkan perestasi non akademik dengan mengembangkan minat dan bakat siswa, (6) menumbuh kembangkan budaya karakter dan budi pekerti yang luhur (7) mewujudkan lingkungan pendidikan sekolah yang aman, rapi, bersih, nyaman, dan berbudaya lingkungan.

$$
\text { Dipilihnya SMPN } 26 \text { Baru }
$$

kota Malang sebagai lokasi penelitian, selain letaknya yang berada dipinggiran kota Malang namun juga sekolah tersebut termasuk lembaga pendidikan yang baru didirikan sehingga semua unsurunsur pendidikan seperti kepala sekolahnya, gurunya, tenaga kependidikannya, peserta didiknya dan sarana prasarananya serba baru.

Berdasarkan paparan di atas, tujuan penilitian ini adalah untuk mengetahui kepemimpinan kepala sekolah SMPN 26 Baru kota Malang dalam upaya meningkatkan mutu pendidikan, untuk mengetahui peran kepala SMPN 26 Baru Kota Malang dalam menjalankan fungsi pengawasan sebagai upaya meningkatkan pro ses pembelajaran di sekolah, untuk mengetahui faktor pendukung dan yang menjadi faktor penghambat kepala SMPN 26 Baru kota Malang dalam menjalankan fungsi pengawasan untuk meningkatkan proses pembelajaran di sekolah.

\section{METODE}

Pendekatan Penelitian ini menggunakan jenis penelitian kualitatif yaitu suatu prosedur penelitian digunakan untuk mendeskripsikan perilaku orang, peristiwa, atau tempat tertentu secara rinci dan mendalam (Bogdan \& Taylor, 1993). Pelaksanaan penelitian bertempat di SMPN 26 Baru kota Malang. Data dalam penelitian kualitatif ini berupa katakata yang dikumpulkan melalui observasi, dokumen dan wawancara, (Miles \& Huberman, 1992).

Sumber data berupa data primer dan data sekunder. Data primer diperoleh berasal dari kepala SMPN 26 Baru kota Malang yang merupakan sebagai subyek dalam penelitian. Selain dari sumber tersebut penulis juga mengambil data dari kegiatan atau aktifitas pembelajaran dalam kesehariannya yang dilaksanakan di Sekolah. Data sekunder diproleh melalui wakil kepala sekolah, waka kurikulum, guru-guru, kepala TU dan staf humas serta dokumen yang terkait dengan penelitian. Untuk memperoleh data yang diinginkan agar focus permasalahan dapat terungkap dalam pengumpulan data ini, peneliti menggunakan teknik studi dokumentasi, observasi partisipan serta melalui wawancara mendalam kepada 5 orang guru, kepala sekolah, waka kurikulum, staf humas, staf TU sekolah. Dengan melihat data yang diteliti, maka instrument pengumpul data adalah peneliti sendiri, dibantu 
dengan seperangkat alat pengumpul data sesuai dengan tujuan penelitian. Dalam hal menganalisis data peneliti berkiblat pada Miles dan (1992), yakni menggunakan tiga tahapan analisis data atau model analisis interaktif digunakan, (1) reduksi data (2) penyajian data, (3) penarikan kesimpulan atau verifikasi.

Untuk menjamin keabsahan data (trustworthiness), maka diperlukan teknik pengecekan. Dalam pelaksanaan teknik pengecekan ini peneliti berdasarkan pada kriteria pengecekan yang diungkapkan oleh Lincoln Guba (1985) Moleong (2002), yaitu: derajat (credibility) , keteralihan (transferability) , kebergantungan (dependability) , dan kepastian (confirmability).

\section{HASIL}

Gaya Kepemimpinan Kepala Sekolah SMPN 26 Baru Kota Malang Sebagai Upaya Meningkatkan Mutu Pendidikan

Berdasarkan hasil wawancara peneliti dengan kepala sekolah, waka kurikulum, waka kesiswaan, humas, tata usaha dan guru senior di SMPN 26 Baru kota Malang ditemukan beberapa pandangan tentang gaya kepemimpinan yang diimplementasikan oleh kepala sekolah SMPN 26 Baru kota Malang. Gaya kepemimpinan yang diterapkan oleh kepala sekolah SMPN 26 Baru kota Malang dalam mempengaruhi bawahannya, cara mengambil keputusan serta kebijakan yakni dengan menggunakan lebih dari satu gaya kepemimpinannya sehingga dalam tataran pelaksanaannya muncul secara situasional. Gaya kepemimpinan situasional yang dimaksud yakni kepala sekolah SMPN 26 Baru kota Malang terkadang menggunakan gaya demokratis partisipatif dan terkadang mengunakan gaya otoriter.

Kepemimpinan demokratis dan partisipatif menjadi pilihan utama kepala sekolah SMPN 26 Baru kota Malang dalam cara mengatur, mengarahkan, membimbing guru dan staf lainnya agar mereka sebagai sesama kolega dapat bekerja sama dalam mencapai tujuan pendidikan yang diharapkan bersama. Kepala sekolah selalu berkonsultasi dengan bawahannya mengenai persoalan yang menarik perhatian mereka dimana mereka dapat menyumbangkan ide-idenya.

Berdasarkan hasil wawancara peneliti dengan kepala urusan kurikulum pada tanggal 8 Agustus 2015 menunjukkan bahwa gaya leadership kepala sekolah SMPN 26 Baru kota Malang melihat bawahannya sebagai partner kerja, memberikan keleluasaan untuk berkembang, membangun kerjasama sebagai tim kerja, memberikan kepercayaan pada bawahan, terbuka atas kritikan yang disampaikan oleh bawahan demi kemajuan bersama, memberikan kebebasan untuk berkreativitas bawahan, memberikan reward bagi yang rajin, memberikan peluang jabatan bagi yang mampu, selalu bermusyawarah untuk menemukan kemufakatan dalam hal tertentu.

Berdasarkan hasil wawancara peneliti dengan kepala sekolah SMPN 26 Baru kota Malang tanggal 6 Juni 2015, dengan wakil kepala sekolah pada tanggal 15 Agustus 
ditemukan bahwa selain gaya kepemimpinan demokratis dan partisipatif di atas, kepala sekolah SMPN 26 Baru kota Malang juga menggunakan gaya otoriter dalam kepemimpinannya. Situasi dan kondisi yang menuntut kepala sekolah untuk bersikap otoriter. Sikap otoriter kepemimpinan kepala sekolah dapat ditunjukkan yakni ketika membuat keputusan sendiri dan hal ini berdasarkan pada prinsip bahwa segala aktivitas dalam lembaga pendidikan atau organisasi akan dapat berjalan mencapai tujuan yang telah ditetapkan apabila semua masalah ditentukan oleh pimpinan dalam hal ini adalah kepala sekolah. Diantara otoriter yang diimplementasikan oleh kepala sekolah SMPN 26 Baru kota Malang adalah tentang penanaman karakter siswa seperti membudayakan siswa membaca asmaul husna setiap pagi tepatnya sebelum mata pelajaran dimulai, mengaji, membaca surat yasin setiap hari jumat, khotmil quran, termasuk juga shalat dhuhur dan ashar berjamaah, selain itu ada juga aturan-aturan yang memang menjadi ketentuan seperti etos kerja, kedisiplinan guru, dan seperti sertifikasi guru sudah menjadi ketentuan guru untuk dilaksanakan dengan baik.

\section{Peran kepala sekolah SMPN 26 Baru kota Malang dalam Menjalankan Fungsi Peng awasan}

Berdasarkan hasil wawancara peneliti dengan kepala sekolah, waka kurikulum, waka kesiswaan, humas, tata usaha dan guru senior secara umum tentang peran kepala sekolah SMPN 26 Baru kota Malang dalam menjalankan fungsi pengawasannya sebagai upaya meningkatkan proses pembelajaran di sekolah ditemukan beberapa peran sebagai berikut: (1) kepala sekolah melakukan pembinaan kepada guru-guru melalui teknik observasi kelas, (2) kepala membuat tahapan-tahapan pelaksanaan teknik supervise observasi kelas, (3) kepala sekolah mendelegasikan guru-guru senior dalam pelaksanaan supervisi observasi kelas.

\section{Bentuk pembinaan terhadap guru melalui teknik supervisi observasi kelas}

Peranan kepala sekolah sebagai supervisor meliputi tugas dan tanggungjawab dalam memantau, membina dan memperbaiki kegiatan pembelajaran di sekolah serta beperan penting terhadap perkembangan dan kemajuan sekolah. Berdasarkan hal tersebut, maka kepala sekolah sebagai pimpinan sekolah harus melaksanakan supervisi secara baik dan benar sesuai dengan prinsip supervisi serta teknik dan pendekatan yang tepat.

Berdasarkan hasil wawancara antara peneliti dengan waka kurikulum pada tanggal 15 Agustus 2015, bahwa kepala sekolah SMPN 26 Baru kota Malang terus berupaya untuk mempertahankan dan mencari terobosan-terobosan baru dalam peningkatan mutu pendidikan di sekolah tersebut. Salah satu upaya yang dilakukan adalah peningkatan kualitas guru dengan memberikan pembinaan yang intensif kepada guru. Pembinaan tersebut dilakukan melalui supervisi teknik individual observasi kelas. Teknik supervisi 
observasi dilakukan secara langsung, melalui supervisi observasi kelas ini kepala sekolah bisa mengetahui secara langsung permasalahan dan kebutuhan guru sehingga pembinaan yang dilakukan bisa efektif karena sudah sesuai dengan kebutuhan guru SMPN 26 Baru kota Malang. Jadi, teknik supervisi berupa observasi kelas lebih mengena dan mudah diterima oleh guru karena pembinaan yang dilakukan oleh kepala sekolah berdasarkan pengalaman atau permasalahan guru di kelas.

Berdasarkan hasil wawancara pada tanggal 12 September antara peneliti dengan ibu Umi Kulsum salah satu guru senior, ditemukan bahwa teknik supervisi observasi kelas secara langsung menjadi pilihan kepala sekolah SMPN 26 Baru kota Malang dalam mensupevisi dikarenakan guru-guru yang ada semuanya adalah guru baru sehingga perlu pembinaan yang ketat agar segera bisa beradaptasi menuju guru yang professional. Oleh karena itu, teknik supervisi observasi kelas dipandang sebagai salah satu supervisi paling tepat dalam memberikan supervisi pembalajaran karena dalam kegiatan tersebut dapat melihat secara langsung kegiatan guru, siswa, dan mengetahui masalah-masalah yang perlu dicarikan solusinya.

Berdasarkan hasil

pengamatan terhadap data dokumentasi, bahwa dipilihnya supervisi observasi kelas bagi guruguru di SMPN 26 Baru kota Malang bertujuan untuk memperbaiki dan meningkatkan kualitas pembelajaran di kelas, meningkatkan kompetensi akademik dan kualitas professional guru terutama dalam pengembangan kurikulum dalam proses pembelajaran di kelas, mampu mengelola dan atau mengatur kegiatan pembelajaran di kelas secara optimal, mengimplementasikan

kompetensinya dalam melaksanakan tugas-tugas mengajarnya, mengembangkan kemampuan sendiri dan memiliki motivasi yang sungguh sungguh.

\section{Tahapan pelaksanaan teknik supervisi observasi kelas}

Berdasarkan hasil wawancara antara peneliti dengan waka sekolah, waka kurikulum, dan waka kesiswaan di di SMPN 26 Baru kota Malang ditemukan bahwa dalam pelaksanaan teknik supervisi observasi kelas telah menyusun kegiatan tersebut dengan perencanaan yang baik yakni berbasis kebutuhan guru.

Pelaksanaan observasi di SMPN 26 Baru kota Malang tersusun terjadwal dalam setiap semesternya. Kemudian agar ada kesiapan bagi guru-guru maka jadwal kegiatan supervisi yang telah dibuat.tersebut didistribusikan ke guru-guru sebelum pelaksanaan supervisi berlangsung. Hasil wawancara peneliti dengan waka kurikulum pada tanggal 15 Agustus 2015, dan kepala sekolah pada tanggal 29 Agustus 2015 menunjukkan bahwa kepala sekolah SMPN 26 Baru kota Malang menerapkan teknik supervisi observasi kelas tidak dilakukan sendirian akan tetapi dengan melakukan pendelegasian kepada guru yang dianggap senior dan berpengalaman dibidangnya serta tergabung dalam tim supervisor untuk melaksanakan teknik supervisi 
observasi kelas tersebut. Pendelegasian ini dimaksudkan supaya supervisi berjalan lebih optimal sesuai dengan target yang diharapkan.

Berdasarkan pengamatan terhadap data dokumentasi, dan hasil wawancara pada tanggal 29 Agustus 2015 antara peneliti dengan kepala sekolah disebutkan bahwa pelaksanaan teknis supervisi observasi kelas di SMPN 26 Baru kota Malang kepala sekolah memberikan penilaian terhadap guru melalui kegiatan prakunjungan kelas, pelaksanaan dan pasca kun jungan kelas. Dalam mensupervisi dengan cara observasi kelas kepala sekolah menilai guru-gurunya sesuai instrument yang ada meliputi: analisis kelengkapan perangkat pembelajarannya, administrasi perencanaan pembelajarannya dan kegiatan proses pembelajaran guru di dalam kelas. Adapun komponen penilaian administrasi meliputi: prota (program tahunan), promes (program semester), silabus, RPP (rencana pelaksanaan pembelajaran), kalender pendidikan, jadwal pelajaran, agenda rutin harian, list nilai, KKM dan absensi peserta didik. Sedangkan komponen supervisi kegiatan pembelajaran yang dinilai adalah (1) kegiatan pendahuluan, (2) kegiatan inti yang meliputi eksplorasi, elaborasi dan konfirmasi kegiatan penutup.

Berdasarkan pengamatan terhadap data dokumentasi, dan hasil wawancara pada tanggal 29 Agustus 2015 antara peneliti dengan kepala sekolah dalam proses pembelajaran dan tindak lanjutnya ditemukan dari 17 guru di SMPN 26 Baru kota Malang yang di supervisi terdapat 4 orang memperoleh predikat sangat baik, dan 10 orang memperoleh nilai baik, serta 3 memperoleh nilai cukup. Kemudian berdasarkan hasil tersebut langkah berikutnya adalah tindak lanjut atas hasil penilaian tersebut. Tindak lanjutnya adalah terdapat 14 guru yang telah di supervisi dapat penghargaan, sedangkan yang 3 orang mendapatkan pembinaan.

\section{Faktor Pendukung, Faktor Penghambat Kepala Sekolah Dalam Menjalankan Fungsi Pengawasan Di SMPN 26 Baru kota Malang}

Berdasarkan hasil wawancara antara peneliti dengan ibu Umi Kulsum selaku guru senior, dengan wakil kepala sekolah, dan dengan kepala sekolah ditemukan bahwa pelaksanaan supervisi observasi kelas oleh kepala sekolah di SMPN 26 Baru kota Malang dipengaruhi dua faktor yaitu faktor pendukung dan faktor penghambat. Berdasarkan hasil wawancara pada tanggal 15 Agustus 2015 antara peneliti dengan ibu Umi Kulsum selaku guru senior, ditemukan bahwa faktor pendukung pelaksanaan teknik supervisi observasi kelas di SMPN 26 Baru kota Malang, diantaranya: (1) para guru selalu siap untuk di supervisi oleh kepala sekolah atau tim supervisi karena menyadari bahwa kegiatan supervisi observasi kelas yang dilakukan kepala sekolah atau tim yang ditunjuk adalah untuk memberikan masukan yang berharga bagi kebaikan proses pembelajaran serta hasil pembelajaran yang dilakukan guru di sekolah, (2) didukung oleh guru pindahan yang berpengalaman, (3) didukung oleh 
semua guru yang sesuai dengan kualifikasi, (4) didukung oleh sarana prasarana yang lengkap.

Berdasarkan hasil wawancara pada tanggal 8 Agustus 2015 antara peneliti dengan wakil kepala sekolah, hasil wawancara pada tanggal 29 Agustus 2015 dengan kepala sekolah, ditemukan bahwa terdapat faktor penghambat pada pelaksanaan teknik supervisi observasi kelas di SMPN 26 Baru kota Malang ini diantaranya, (1) adanya kesulitan yang dialami oleh kepala sekolah atau tim supervise jika kepala sekolah atau tim supervisi dalam mensupervisi guru yang bukan bidang studi yang menjadi background pendidikan kepala sekolah atau tim supervisi, (2) adanya jumlah siswa yang terlalu gemuk perbandingan rasio guru dengan siswa tidak seimbang yakni antara 1 guru : 40 siswa.

Berdasarkan hasil wawancara pada tanggal 29 Agustus 2015 antara peneliti dengan kepala sekolah, menunjukkan bahwa secara keseluruhan pelaksanaan teknik supervisi observasi kelas di SMPN 26 Baru kota Malang berdampak positif terhadap guru-guru yakni senantiasa dapat mengajar lebih baik setelah dilaksanakannya teknik supervisi observasi kelas, hal itu karena dapat merefleksikan segenap kekurangan dan kelebihannya selama proses belajar-mengajar berlangsung. Untuk itu, atas dasar faktor pendukung dan faktor penghambat pelaksanaan teknik supervisi observasi kelas yang ada maka segenap kelebihan supaya terus dipertahankan dan ditingkatkan, sedangkan kekurangan agar terus diperbaiki guna menuju pembelajaran bermutu dan berkualitas sehingga pada akhirnya akan tercapai hasil yang berkualitas pula.

\section{PEMBAHASAN}

Kepemimpinan Kepala Sekolah Di SMPN 26 Baru Kota Malang Dalam Upaya Meningkatkan Mutu Pendidikan

Pendidikan di sekolah sebagai institusi pendidikan formal diharapkan dapat meningkatkan kualitas SDM. Dalam upaya peningkatan mutu, diperlukan pengelolaan yang baik, diatur dan ditata, serta diberdayakan, agar supaya menghasilkan out-put atau produk secara optimal. Kepala sekolah sebagai seorang yang diberi tugas untuk memimpin sekolah, memiliki tanggung jawab atas tercapainya visi, misi, tujuan, peran, dan mutu. Salah satu kunci yang sangat signifikan menentukan mutu dan keberhasilan sekolah dalam mencapai visi, misi serta tujuannya adalah kepala seko- lah itu sendiri. Keberhasilan kepemimpinan kepala sekolah secara dominan tidak lepas dari kemahiran dan keandalan manajemen yang dibangun di sekolah yang bersangkutan, sedangkan keandalan manajemen yang dikonstruk di sekolah sangat dipengaruhi oleh kemampuan dalam menggunakan kepemimpinannya yakni perilaku kepemimpinan yang efektif atau gaya kepemimpinan. Menurut Tilaar (2000;158) pemimpin adalah jenderal lapangan yang memiliki kendali berbagai taktik dan strategi untuk melaksanakan program kegiatan yang telah disepakati. Lebih dari itu, pemimpin seharusnya memiliki 
gagasan yang terus berkembang terutama yang terkait dengan strategi untuk memajukan organisasi yang dipimpinnya.

SMPN 26 Baru kota malang salah satu sekolah negeri yang baru didirikan dibutuhkan kecermatan atau membaca situasi bagi seorang kepala sekolah sebagai pemimpinnya di institusi tersebut. Burhanuddin (2002; 138) mengungkapkan bahwa kepemimpinan di lembaga pendidikan sekolah yang berhasil yakni suatu proses kepemimpinan yang dapat memenuhi kebutuhan dari masing-masing situasi, serta dapat memilih atau menerapkan teknik atau perilaku kepemimpinannya yang sesuai dengan situasi. Gaya atau Perilaku kepemimpinan yang diimplementasikan oleh kepala SMPN 26 Baru kota Malang dalam mempengaruhi bawahannya, cara mengambil keputusan serta kebijakan yaitu dengan menggunakan gaya atau perilaku kepemimpinannya lebih dari satu. Sehingga dalam pelaksanaan kepemimpinannya, gaya atau perilaku kepemimpinan tersebut muncul secara situasional. Kepemimpinan situasional dimaksud adalah kepala sekolah SMPN 26 Baru kota Malang terkadang gaya demokratis partisipatif dan terkadang mengunakan gaya otoriter.

Penelitian ini mendukung pendapat Burhanuddin (2002;138) yang menyebutkan bahwa kepala sekolah selalu dihadapkan dengan faktor manusia seperti guru-guru, siswa, dan orang tua sebagai komponen penting bagi kelangsungan sekolah, maka kepala sekolah harus berusaha memahami kelompok ini sebagai kelompok individu memiliki kepribadian yang berbeda, berdasarkan pada pemahaman terhadap tingkat-tingkat perkembangan guru yang ada akan menentukan kadar perilaku kepemimpinan efektif yang dibutuhkah yakni direktif dan suportif.

Gaya kepemimpinan demokratis partisipatif menjadi pilihan utama kepala sekolah SMPN 26 Baru kota Malang dalam cara mengatur, mengarahkan, membimbing staf dan guru-guru agar mereka bekerja sama guna mencapai tujuan pendidikan. Kepala sekolah selalu berkonsultasi dengan bawahannya mengenai masalah yang menarik perhatian mereka dimana mereka dapat menyumbangkan ideidenya. Gaya atau perilaku kepemimpinan kepala sekolah SMPN 26 Baru kota Malang memandang bawahan sebagai kolega, memberi kebebasan untuk berkembangan, memandang bawahan sebagai mitra kerja, membangun kerjasama sebagai tim kerja, memberikan kepercayaan pada bawahan, terbuka atas kritik selama untuk kemajuan bersama, memberikan kebebasan untuk berkreasi kepada bawahan, memberikan reward bagi yang rajin, memberikan peluang jabatan bagi yang mampu, selalu bermusyawarah untuk mencapai kemufakatan dalam hal tertentu.

Selain menggunakan gaya demokratis di atas, kepala sekolah SMPN 26 kota Malang juga menggunakan gaya otoriter dalam kepemimpinannya. Tuntutan situasi dan kondisi yang membuat kepala sekolah untuk bersikap otoriter. Sikap otoriter yang dimaksud adalah 
kepala sekolah membuat keputusan sendiri dan berdasarkan pendirian bahwa segala aktifitas dalam organisasi akan dapat berjalan lancar dan berhasil mencapai tujuan yang telah ditentukan apabila semua masalah diputuskan atau ditentukan oleh sekolah kepala sekolah sebagai seorang pemimpin. Diantara gaya otoriter yang dilakukan oleh kepala SMPN 26 kota Malang adalah kebijakan tentang penanaman karakter siswa seperti membudayakan siswa membaca asmaul husna setiap pagi tepatnya sebelum mata pelajaran dimulai, mengaji, baca yasin setiap hari jumat, khotmil quran, termasuk juga dhuhur shalat dan ashar berjamaah. Selain itu juga ada aturan- aturan yang memang menjadi ketentuan seperti etos kerja, kedisiplinan guru, dan seperti sertifikasi guru sudah menjadi ketentuan guru untuk dilaksanakan dengan baik.

Penelitian ini sependapat dengan Mulyasa $(2003 ; 116)$ yang mengatakan bahwa dalam hal tertentu yakni dalam pengambilan suatu keputusan maka kehadiran sifat kepemimpinan otoriter lebih cepat digunakan. Penelitian ini juga menerima pendapat Qomar (2007;274) yang mengatakan bahwa sikap seorang pemimpin pada saat situasi darurat walaupun tanpa musyawarah terlebih dahulu harus ada keberanian, kesigapan dan kecepatan dalam mengambil sikap. Keberanian, kecepatan, dan ketepatan seorang leader dalam mengatasi masalah yang mendesak memang bukan sesuatu yang mudah, dibutuhkan kecerdasan dan kecermatan yang tinggi. Jika dihadapkan dengan situasi yang sangat sulit maka pemimpin dianjurkan memilih pilihan yang memiliki resiko paling kecil.

Dengan dimilikinya beberapa gaya kepemimpinan untuk suatu organisasi sekolah dalam hal ini untuk kepala sekolah, maka dapat disarankan menggunakan strategi yang tepat dan sesuai dengan situasi dan kondisi dalam menjalankan tugasnya sebagai kepala sekolah.

Hal tersebut di atas sesuai dengan empat gaya dasar kepemimpinan situasional P. Hersey dan K. Blanchard yang dapat dijadikan acuan kepala sekolah, seperti pada gambar, berikut :

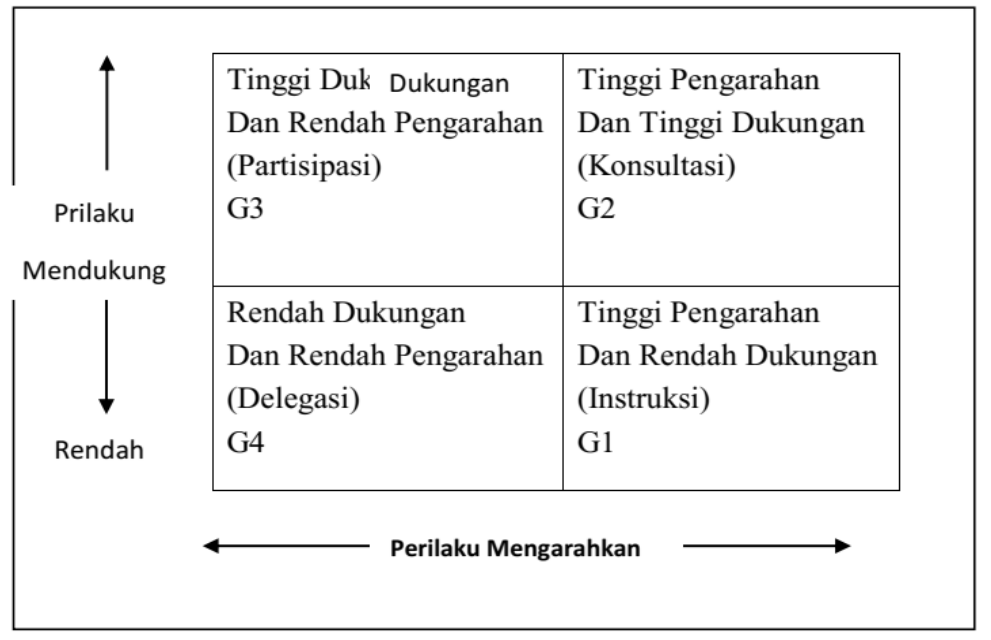




\section{Empat Gaya Dasar}

Kepemimpinan Situa sional

Gaya 1: Seorang pemimpin menunjukkan perilaku yang banyak memberikan pengarahan dan sedikit dukungan. Pemimpin ini memberikan instruksi yang spesifik tentang peranan dan tujuan bagi pengikuitnya, dan secara ketat mengawasi tugas mereka. Dalam hal ini pemimpin memberikan batasan peranan pengikutnya dan memberitahu mereka tentang apa, bagaimana, bilamana dan dimana melaksanakan berbagai tugas. Inisiatif pemecahan masalah dan pembuatan keputusan semata-mata dilakukan oleh pemimpin. Pemecahan masalah dan keputusan diumumkan, dan pelaksanaannya diawasi secara ketat oleh pemimpin.

Gaya 2: Pemimpin menunjukkan perilaku yang banyak mengarahkan dan banyak memberikan dukungan. Dalam gaya ini dirujuk sebagai konsultasi, karena dalam menggunakan gaya ini, pemimpin masih banyak memberikan pengarahan dan masih membuat hampir sama dengan keputusan, tetapi hal ini diikuti dengan meningkatkan banyaknya komunikasi dua arah dan perilaku mendukung, dengan berusaha men dengar perasaan pengikut serta ideide dan saran-saran mereka. Tetapi tetap pemimpin harus terus memberikan pengawasan dan pengarahan dalam penyelesaian tugas-tugas pengikutnya.

Gaya 3: Perilaku pemimpin menekankan pada banyak memberikan supportive dan sedikit pengarahan. Gaya ini dirujuk sebagai partisipasi, karena posisi kontrol atas pemecahan masalah dan pembuat keputusan yang dipegang secara bergantian. Dengan penggunaan gaya 3 ini, pemimpin dan pengikut saling tukar menukar ide dalam pemecahan masalah, komunikasi dua arah ditingkatkan, dan pemimpin juga mmendukung usaha-usaha mereka dalam menyelesaikan tugas pengikutnya. - beri kan sedikit dukungan dan sedikit peng- arahan.

Gaya 4 : Perilaku pemimpin yang memberikan sedikit dukungan dan sedikit pengarahan. Gaya ini dirujuk sebagai delegasi, karena pemimpin mendiskusikan masalah dengan bawahan sehingga tercapai kesepakatan mengenai definisi masalah yang kemudian yang kemudian proses pembuat keputusan didelegasikan secara keseluruhan kepada bawahan. Pemimpin memberi kesempatan seluas-luasnya terhadap bawahan untuk melakasanakan pengontrolan atas tugas-tugasnya, karena mereka memiliki kompetensi dan motivasi yang tinggi untuk mengemban tanggung jawab dalam pengarahan perilaku mereka sendiri.

Berdasarkan uraian di atas, menunjukkan bahwa empat gaya dasar kepemimpinan tersebut merupakan hal yang penting dan menjadi landasan kepemimpinan seseorang dalam hubungannya dengan perilaku pemimpin itu sendiri dalam mempengaruhi bawahannya yakni perilaku mengarahkan dan mendukung yang pada nantinya akan melibatkan hubungan kerja yang berorientasi akan tugas.

\section{Peran Kepala Sekolah SMPN 26 Baru Kota Malang Menjalankan Fungsi Pengawasan di Sekolah}

Berdasarkan data penelitian 
ini menunjukkan peran kepala sekolah SMPN 26 Baru kota Malang dalam menjalankan fungsi pengawasannya untuk meningkatkan proses pembelajaran di sekolah diantaranya, (1) Kepala sekolah melakukan pembinaan kepada guruguru melalui teknik supervis observasi kelas (2) Kepala sekolah membuat tahapan-tahapan pelaksanaan supervisi kelas, (3) sekolah guru-guru senior pelaksanaan observasi kelas.

\section{Bentuk pembinaan terhadap guru melalui supervisi observasi kelas}

Tugas dan tanggungjawab kepala sekolah sebagai supervisor memiliki peran yang sangat penting dalam me- mantau, membina dan memperbaiki dalam kegiatan pembelajaran di sekolah serta peranannya terhadap perkembangan dan kemajuan sekolah. Oleh karena itu kepala sekolah harus melaksanakan secara baik dan benar sesuai pada prinsip-prinsip supervisi serta teknik dan pendekatan yang tepat.

Kepala sekolah SMPN 26 Baru kota Malang terus berupaya melaksankan kegiantan- kegiatan yang mendukung terhadap peningkatkan kualitas pendidikan di sekolah tersebut. Upaya yang saat ini dilakukan adalah peningkatan kualitas guru dengan memberikan pembinaan yang intensif kepada guru. Pembinaan tersebut dilakukan melalui supervisi dengan teknik supervisi individual observasi kelas. Teknik supervisi observasi dilakukan secara langsung, dengan supervisi observasi kelas kepala sekolah bisa mengetahui secara langsung permasalahan dan kebutuhan guru sehingga pembinaan yang dilakukan sangat efektif karena dapat memenuhi kebutuhan guru di SMPN 26 Baru kota Malang. Jadi, teknik supervisi observasi kelas lebih mengena dan mudah diterima oleh guru karena pembinaan kepala sekolah berdasarkan pengalaman atau permasalahan guru di kelas.

Teknik supervisi observasi kelas secara langsung menjadi pilihan kepala sekolah SMPN 26 Baru kota Malang dalam mensupervisi dikarenakan guru-guru yang ada semuanya adalah guru baru sehingga perlu pembinaan yang ketat agar segera bisa beradaptasi menuju guru yang professional. Supervisi observasi kelas dipandang sebagi salah teknik supervisi yang paling tepat dalam memberikan supervisi karena dalam kegiatan teknik supervisi observasi kelas dapat memantau dan mengamati kegiatan guru, siswa, dan masalah yang timbul.

Penelitian ini mendukung
pandangan Glickman tentang
supervisi dalam Buku Developmental
$\begin{aligned} & \text { Supervision (1981)) yang } \\ & \text { menggambarkan }\end{aligned}$ supervisi pendidikan sebagai berikut: (1) pandangan directive supervisi pendidikan dilakukan manakala memiliki tanggung jawab rendah, sedangkan supervisor memiliki tanggung jawab tinggi, sebaliknya non directive jika guru tanggung jawab tinggi sementara supervisor memiliki tanggung jawab rendah, collaborative jika tanggung jawab guru dan supervisor sama-sama sedang.

Penelitian ini juga sesuai dengan Arikunto (2002: 381) yang 
menyatakan bahwa teknik supervisi observasi kelas adalah kegiatan supervisi yang dilakukan dengan cara menunggu guru (calon guru) yang sedang melaksanakan proses belajar mengajar dari awal pelajaran hingga akhir pelajaran. Supervisi Observasi kelas inilah kegiatan supervisi paling teliti dan sistematis sebab mengamati semua gerak gerik guru yang sedang melaksanakan proses belajar mengajar.

$$
\text { Dipilihnya }
$$

supervisi observasi kelas bagi guru-guru SMPN 26 Baru kota Malang bertujuan untuk mengembangkan kualitas pembelajaran di kelas dengan cara membina dan melakukan perbaikan manakala ditemukan kesalahan-kesalahan dalam melaksanakan tugasnya di dalam kelas, meningkatkan kompetensi akademik dan kualitas professional guru terutama dalam pengembangan kurikulum dalam proses pembelajaran di kelas, mampu mengelola dan atau mengatur kegiatan proses belajar mengajar di dalam kelas secara optimal, mengimplementasikan

kompetensinya dalam melaksanakan tugas-tugas mengajarnya, mengembangkan kemampuan sendiri dan memiliki perhatian yang sungguh sungguh.

\section{Tahapan pelaksanaan teknik supervisi observasi kelas}

Kepala SMPN 26 Baru kota

Malang dalam mensupervisi observasi kelas telah menyusun kegiatan tersebut dengan perencanaan yang baik yakni berdasarkan kebutuhan guru. Penelitian ini sesuai dengan arahan Arikunto (2006:54) bahwa dalam mengobservasi perlu memperhatikan beberapa hal, antara lain: tujuan yang akan dicapai, apa yang akan diobservasi, kreteria dan alat-alat yang dipakai dalam observasi.

Perencanaan merupakan suatu hal yang sangat pokok dan penting dalam mencapai suatu tujuan. Supervisi sebagai usaha mendorong para guru mengembangkan kom- petensinya. Tanpa perencanaan yang baik jangan diharapkan tujuan pendidikan akan tercapai, maka program supervisi pembelajaran harus dibuat sebagai patokan dalam melaksanakan tugas.

$$
\text { Pelaksanaan supervisi }
$$

observasi kelas di SMPN 26 Baru kota Malang tersusun dan terjadwal dalam setiap semesternya. Kemudian jadwal kegiatan supervisi telah dibuat tersebut didistribusikan kepada guru-guru sebelum pelaksanaan berlangsung sehingga dengan seperti itu ada kesiapan bagi guru. Penelitian ini sesuai dengan pernyataan Effendi (2002) bahwa perencanaan adalah kegiatan rasional yang sistematis dalam menentukan kebijaksanaan, prioritas, kegiatan atau langkah kegiatan yang akan dilakukan dikemudian hari untuk mencapai tujuan yang telah ditentukan.

Penelitian ini juga sesuai dengan pendapat Sagala (2009 : 125) bahwa program atau kegiatan supervisi di sekolah adalah program pengembangan guru yang kegiatannya dirancang dengan tematema yang berkisar pada penyajian informasi tentang jenis pen- dekatan, membantu guru memahami informasi, membantu guru mengaplikasikan pengajaran, dan membantu guru memahami tingkat 
pengetahuan serta integrasi nilai dan sikap.

Kepala sekolah SMPN 26

Baru kota Malang melakukan supervisi kelas tidak dilakukan sendirian akan tetapi dengan cara pendelegasian terhadap guru-guru yang terbilang senior dan berpengalaman dibidangnya serta tergabung dalam tim supervisor untuk melaksanakan tugas supervisi kelas tersebut. Pendelegasian ini dimaksudkan supaya supervisi berjalan optimal sesuai dengan target yang diharapkan.

Berdasarkan pada pemahaman itu penelitian ini pendapat (2007: yang bahwa kelas ini melalui tahap, : (1) observasi (2) observasi (3) pelaksanaan; (4) hasil dan lanjut. melaksanakan observasi kelas ini sebaiknya supervisor menggunakan instrumen observasi tertentu yakni berupa evaluative chek- list, dan activite chek- list .

$$
\text { Pelaksanaan supervisi }
$$

observasi kelas di SMPN 26 Baru

kota Malang kepala sekolah memberikan penilaian terhadap guru melalui tahapan kegiatan prakunjungan, pelaksanaan dan pasca kunjungan. Sesuai dengan instrumen penilaian yang ada maka setiap guru secara garis besarnya di assesment terkait kelengkapan dokumen, perangkat pembelajaran, administrasi perencanaan pembelajaran dan kegiatan proses pembelajaran guru selama di dalam kelas. Komponen adminstrasi yang dinilai adalah: tahunan, promes, silabus, rpp, kalender pendidikan, jadwal pelajaran, agenda harian, list nilai, KKM dan absensi peserta didik. Sedangkan komponen supervisi kegiatan pembelajaran yang dinilai
(1) kegiatan pendahuluan, (2) kegiatan inti yang meliputi eksplorasi, elaborasi dan konfirmasi (3) kegiatan penutup.

Berdasarkan pengamatan terhadap data dokumentasi yang diperoleh peneliti terkait hasil proses dan tindak lanjutnya dari 17 guru SMPN 26 kota Malang yang disupervisi ada 4 orang memperoleh predikat sangat baik, dan 10 orang memperoleh nilai baik, serta 3 memperoleh nilai cukup. Kemudian langkah berikutnya adalah tindak lanjut atas hasil penilaian tersebut. Adapun tindak lanjut yang harus dilakukan bagi guru yang disupervisi 14 orang dapat penghargaan, sedangkan yang 3 orang mendapatkan pembinaan.

\section{Faktor Pendukung dan Penghambat Kepala Sekolah SMPN 26 kota Malang dalam Menjalankan Fungsi Pengawasan di Sekolah}

Pelaksanaan supervisi observasi kelas kepala sekolah SMP 26 Baru kota Malang dipengaruhi faktor pendukung dan penghambat.

Faktor pendukung supervisi observasi kelas di SMPN 26 Baru kota Malang, diantaranya: (1) guru siap untuk disupervisi oleh kepala sekolah atau tim supervisi karena menyadari bahwa kegiatan supervisi observasi kelas yang dilakukan kepala sekolah atau tim yang ditunjuk adalah untuk memberikan masukan yang berharga bagi kebaikan proses dan hasil pembelajaran yang guru sekolah, didukung oleh pindahan berpengalaman, didukung oleh semua guru yang sesuai dengan kualifikasi, didukung sarana yang 
lengkap.

Sedangkan faktor penghambat pada pelaksanaan observasi kelas di SMPN 26 Baru kota Malang ini diantaranya, (1) adanya beberapa kesulitan yang dialami kepala sekolah atau tim supervisi jika kepala sekolah atau tim supervisi mensupervisi guru yang bukan bidang studi yang menjadi background pendidikan kepala sekolah atau tim supervisi, (2) adanya ketidak seimbangan rasio guru dengan siswa yakni 1 guru : 40 siswa.

Secara keseluruhan pelaksanaan supervisi observasi kelas di SMPN 26 Baru kota Malang berdampak positif pada gurugurunya yakni senantiasa dapat mengajar lebih baik setelah adanya supervisi observasi kelas karena dapat merefleksikan segenap kekurangan dan kelebihannya selama proses belajar mengajar berlangsung. Untuk itu, atas dasar faktor pendukung dan yang menjadi penghambat pelaksanaan supervisi observasi kelas yang ada maka segenap kelebihan supaya terus dipertahankan dan ditingkatkan, sedangkan kekurangan agar terus diperbaiki guna menuju proses pembelajaran yang berkualitas untuk mencapai out put yang berkualitas pula.

\section{KESIMPULAN DAN SARAN}

Kesimpulan penelitian ini adalah sebagai berikut: (1) Dalam mempengaruhi bawahannya, dan cara mengambil keputusan serta kebijakan kepala sekolah SMPN 26 Baru kota Malang menggunakan gaya kepemimpinan lebih dari satu, yakni kepemimpinan demokratis partisipatif menjadi pilihan utama, dalam hal tertentu dan sifatnya mendesak mengunakan gaya kepemimpinan otoriter, gaya kepemimpinan muncul secara situasional, (2) Dalam meningkatkan proses pembelajaran di kelas kepala SMPN 26 Malang memberikan pembinaan yang intensif terhadap guru-gurunya melalui supervisi teknik individual observasi secara langsung. Kepala SMPN 26 Baru kota Malang menyusun kegiatan tersebut dengan perencanaan yang baik yakni berbasis pada kebutuhan guru.

Dipilihnya supervisi observasi kelas bagi guru-guru SMPN 26 Baru kota Malang bertujuan untuk memperbaiki dan mengembangkan kualitas pembelajaran di kelas, meningkatkan kompetensi akademik dan kualitas profesional guru terutama dalam pengembangan kurikulum dan proses belajar mengajar di kelas, mampu mengelola dan atau mengatur kegiatan proses belajar mengajar di kelas secara optimal, mengimplementasikan

kompetensinya dalam melaksanakan tugas-tugas mengajarnya, mengembangkan kemampuan sendiri dan memiliki perhatian yang sungguh sungguh.

Pelaksanaan supervisi observasi kelas berdampak positif terhadap guru-guru ditemukan dari 17 guru SMPN 26 kota Malang yang disupervisi terdapat 4 orang memperoleh predikat sangat baik, dan 10 orang memperoleh nilai baik, serta memperoleh cukup. hanya orang dapat (3) Pelaksanaan supervisi individual, supervisi observasi kelas secara langsung 
dipengaruhi oleh faktor eksternal dan faktor internal, baik yang mendukung maupun yang menjadi penghambat.

Dari hasil penelitian ini, penulis ingin menyampaikan beberapa saran sebagai berikut, (1) Bagi pendidik, hendaknya dapat dijadikan salah satu acuan pengembangan dan peningkatan kualitasnya, (2) Bagi kepala sekolah atau pengawas sekolah, hendaknya dapat menjadi bahan informasi yang berguna dalam menentukan gaya kepemimpinannya dan berguna dalam melaksanakan pembinaan profesionalitas guru, (3) Bagi pemerintah, khususnya bagi kemendikbud hendaknya dapat menjadikan hasil penelitian sebagai bahan kajian dan informasi dalam mengupayakan peningkatan kualitas guru di sekolah-sekolah naungannya, (4) Bagi pengembangan ilmu pengetahuan, dapat diman faatkan untuk memperkaya wawasan keil muwan dan sebagai bahan informasi serta referensi yang layak bagi peneliti selanjutnya yang ingin meneliti kasus- kasus sejenis.

\section{DAFTAR RUJUKAN}

Bogdan. R.C, dan Biklen, S.K. Qualitative Research Education Boston: Allyn and Bacon Choliq MT. 2011. Supervisi Pendidikan. Yogyakarta: Mitra Cendekia.

Depdiknas Direktorat Pembinaan SMP.2006. Pembakuan Bangunan dan Perabot SMP, Jakarta: Direktorat Pembinaan SMP.

Mulyasa, E.. 2009. Menjadi Kepala
Sekolah Profesional, Bandung: PT Remaja Rosdakarya.

Glickman, $\quad$ C.D. 1981. Developmental Supervision: Alternative Practices for Helping Teachers, Improve Instruction, ASCD(Association for Supervision and Curriculum Devel - opment), Alexandria, Virgini.

Moleong, J. 2006. Metodologi Kualitatif . Bandung: Remaja Rosda Karya.

Miles dan Huberman. 1987. Analisis Kualitatif. Terjemahan. Jakarta: Yayasan penerbitan Universitas Indonesia.

Mulyasa, E. 2008. Standar Kompetensi dan Sertifikasi Guru. Bandung: PT. Remaja Rosdakarya.

Mulyasa, E. 2007. Menjadi Guru Profesional Menciptakan Pembelajaran Kreatif dan

Me nyenangkan . Bandung: PT. Remaja Rosdakarya.

Miftah, T. 2003. Kepemimpinan Dalam Manajemen, Jakarta: PT Raja Grapindo.

Nawawi, 2005. Manajemen Sumber Daya Mannusia. Yogyakarta: Gajah Mada

University Press.

Nasution. 2006. Metode Reseach (Penelitian ilmiah). Jakarta: Bumi Aksara.

Purwanto, 2004. Administrasi dan Supervisi Pendidikan, Bandung: Rosdakarya. 
Jurnal Filsafat, Sains, Teknologi, dan Sosial Budaya

Volume 22, Nomor 2, Juli-Desember 2016

Sagala, S. 2010. Supervisi

Pembelajaran dalam Profesi Pendidikan. Bandung : Alfabeta. Sahertian, P. A. 2008. Konsep Dasar dan Teknik Supervisi Pendidikan, dalam Rangka Pengem bangan Sumber Daya Manusia. Jakarta: Rineka Cipta.

Sugiyono. 2011. Metode Penelitian Kuantitatif Kualitatif Dan $R \& D$. Bandung: Alfabeta.

Sally J. Z. 2003. Instructiona Supervision Applying Tools Concepts, Eye On Education, Library Conggres Publication Data.

Robbin, S. P. 2001. Organizational Behavior, New Jersey: Prentice Hall International.

Undang-Undang Indonesia 20 Tahun 2003 edisi 2009. Sistem Pendidikan Nasional, Bandung, Depdiknas, Citra Umbara.

Yin , K. 2006. Studi Kasus: Desain dan Metodologi, penerjemah. Djauzi Mundakir. Jakarta: PT Raja Grafindo.

Wahjosumijo. 2002. Kepemimpinan Kepala Sekolah, Jakarta: PT Raja Grafindo Persada 